Journal of Animal and Veterinary Advances 9 (14): 1899-1901, 2010

ISSN: $1680-5593$

(C) Medwell Journals, 2010

\title{
Determination of Heat and Moisture Balance for Broiler House
}

\author{
Adil Akyuz and Sedat Boyaci \\ Department of Farm Structures and Irrigation Science, \\ Kahramanmaras Sutcu Imam University, Kahramanmaras, Turkey
}

\begin{abstract}
The aim of this study was carried out to determine the heat and humidity balance for one of broiler houses as an example of the broiler house based on the traditional poultry production systems in Kahramanmaras, Turkey. In the first period in February and March, inside temperature of broiler house was lower than the optimal temperature whereas inside relative humidity of broiler house was close to the optimum relative humidity level. In the second period in August and September inside temperature of broiler house at 2nd week was close to the optimal temperature whereas the inside temperature of broiler house at 3-7 weeks was higher than the optimal temperature. On the other hand, inside relative humidity of broiler house at 3-7 weeks of second period was lower than the optimum relative humidity level. In the first period in February and March sensible heat dissipated by broiler was ranged from $1.20-4.50 \mathrm{kcal} \mathrm{h}^{-1}$, moisture from $1.30-4.20 \mathrm{~g} \mathrm{~h}^{-1}$ and net heat output through the structural elements from $8.40-14.00 \mathrm{kcal} \mathrm{m}^{-2}{ }^{\circ} \mathrm{C}$. In the second period in August and September, Sensible heat dissipated by broiler was ranged from $0.80-4.50 \mathrm{kcal} \mathrm{h}^{-1}$, Moisture from $0.80-4.20 \mathrm{~g} \mathrm{~h}^{-1}$ and the net heat output through the structural elements from $1.10-3.80 \mathrm{kcalm}^{-20} \mathrm{C}$. Although, there is need for supplementary heat during the first period in February and March there is no need for supplementary heat during the first period in August and September for poultry house in Kahramanmaras, Turkey.
\end{abstract}

Key words: Broiler, heat stress, heat balance, humidity balance, broiler house, Turkey

\section{INTRODUCTION}

Broiler chicken industry has continuously grown recently and is considered an important livestock sector in Turkey as in many countries (Atilgan and Koknaroglu, 2006). Although, the feed accounts for $70-80 \%$ of the production cost of poultry (Karaman et al., 2009), there are some other factors affecting the production cost of poultry such climatic conditions inside the poultry house. Heat, humidity ammonia and carbon dioxide in poultry house have a negative effect on broiler performance (Atilgan et al., 2010).

As in many developing countries, some of poultry population in Turkey is found in the traditional family based poultry production systems. In such production systems high ambient temperatures can be devastating to commercial broilers coupled with high humidity they can have an even more harmful effect. Heat stress interferes with the broilers comfort and suppresses productive efficiency.

During periods of heat stress the broiler has to make major thermo regulatory adaptations in order to prevent death from heat exhaustion (Butcher and Miles, 1996). The aim of this study was carried out to determine the heat and humidity balance for one of broiler houses as an example of the broiler house based on the traditional poultry production systems in Kahramanmaras, Turkey.

\section{MATERIALS AND METHODS}

This experiment was carried out in broiler house in Kahramanmaras Sutcu Imam University Experimental Farm, in Kahramanmaras, Turkey for two periods. First period lasted 5 weeks in February and March. Second period lasted 6 weeks in August and September. In the current experiment ROSS chicks were used. In this study, 4 humidity sensors and 12 temperature sensors were used in broiler house and 1 humidity sensor and 1 temperature sensor outside of broiler house.

The measurement of humidity and temperature of inside and outside of broiler house were carried out at three different time points of a day $(7.00 \mathrm{am}, 14.00 \mathrm{pm}$ and $21.00 \mathrm{pm}$ ) using data logger with sensors. The means of daily temperature and humidity were estimated as follow:

$$
\text { Mean temperature }\left({ }^{\circ} \mathrm{C}\right)=\frac{\mathrm{t}_{7}+\mathrm{t}_{14}+2 \mathrm{t}_{21}}{3}
$$

Corresponding Author: Adil Akyuz, Department of Farm Structures and Irrigation Science, Kahramanmaras Sutcu Imam University, Kahramanmaras, Turkey 
Mean humidity $(\%)=\frac{\mathrm{n}_{7}+\mathrm{n}_{14}+\mathrm{n}_{21}}{3}$

The general heat balance for the broiler house was calculated as follow:

$$
\mathrm{q}_{\mathrm{d}}=\mathrm{q}_{\mathrm{h}}+\mathrm{q}_{\mathrm{y}}
$$

Where:

$\mathrm{q}_{\mathrm{d}}=$ Sensible heat dissipated by broiler $\left(\mathrm{kcal} \mathrm{h}^{-1}\right)$

$\mathrm{q}_{\mathrm{h}}=$ Heat output through ventilation

$\mathrm{q}_{\mathrm{y}}=$ The net heat output through the structural elements (roof, wall, window, door) follow:

Heat output through ventilation was calculated as

Where:

$$
\mathrm{q}_{\mathrm{h}}=0.29 \times \mathrm{Q}_{\mathrm{h}} \times\left(\mathrm{t}_{\mathrm{i}}-\mathrm{t}_{\mathrm{d}}\right)
$$

$\mathrm{Q}_{\mathrm{h}}=$ Minimum ventilation discharge rate

$\mathrm{t}_{\mathrm{i}}=$ Inside temperature of house

$t_{d}=$ Outside temperature of house

The net heat output through the structural elements was calculated as follow:

Where:

$$
\mathrm{q}_{\mathrm{y}}=\mathrm{U}_{\mathrm{y}} \times \mathrm{A}_{\mathrm{y}} \times\left(\mathrm{t}_{\mathrm{i}}-\mathrm{t}_{\mathrm{d}}\right)
$$

$\mathrm{U}_{\mathrm{y}}=$ Heat transfer coefficient of structure

$\mathrm{A}_{\mathrm{y}}=$ Surface area of structure

$\mathrm{t}_{\mathrm{i}}=$ Inside temperature of house

$t_{d}=$ Outside temperature of house

The heat transfer coefficient of structure $\left(\mathrm{U}_{\mathrm{y}}\right)$ was calculated as follow:

$$
\mathrm{U}_{\mathrm{y}}=\frac{1}{\frac{1}{\mathrm{f}_{\mathrm{i}}}+\sum_{\mathrm{i}=1}^{\mathrm{n}} \frac{\mathrm{d}_{\mathrm{i}}}{\mathrm{k}_{\mathrm{i}}}+\frac{1}{\mathrm{f}_{\mathrm{d}}}}
$$

Where:

$\mathrm{f}_{\mathrm{i}}=$ Inside heat conductance

di $=$ Thickness of structure

$\mathrm{k}_{\mathrm{i}}=$ Thermal conductivity of structure

$f_{d}=$ Outside heat conductance

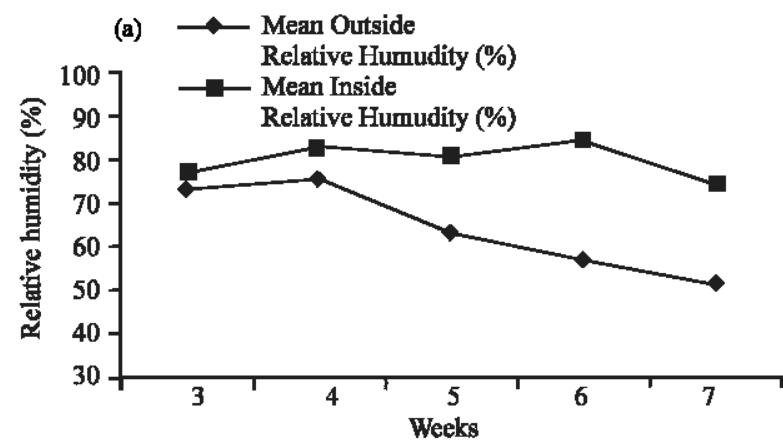

The general moisture balance for the broiler house was calculated as follow:

$$
\mathrm{W}_{\mathrm{h}}=\mathrm{G} \times\left(\mathrm{W}_{2}-\mathrm{W}_{1}\right)
$$

Where:

$\mathrm{W}_{\mathrm{h}}=$ Moisture released by poultry

$\mathrm{G}=$ Ventilation amount $\left(\mathrm{kg} \mathrm{h}^{-1}\right)$

$\mathrm{W}_{1}=$ Absolute air moisture $\left(\mathrm{g} \mathrm{m}^{-3}\right)$ inside the house

$\mathrm{W}_{2}=$ Absolute air moisture $\left(\mathrm{g} \mathrm{m}^{-3}\right)$ outside the house

\section{RESULTS AND DISCUSION}

The temperature and humidity values of 5 weeks in the first period (in February and March) are shown in Fig. 1. Lindley and Whitaker (1996) indicated that optimum inside temperature of broiler house should be $32-33^{\circ} \mathrm{C}$ in 1-2 weeks and $21^{\circ} \mathrm{C}$ in 3-7 weeks. In the current experiment inside temperature of broiler house in February and March was lower than the optimal temperature.

Ekmekyapar indicated that optimum inside relative humidity of broiler house should be $40-70 \%$ in 1-2 weeks and $65-70 \%$ in 3-7 weeks. In the current experiment inside relative humidity of broiler house was close to the optimum relative humidity level. The temperature and humidity values of 6 weeks in the second period (August and September) are shown in Fig. 2.

In the current experiment inside temperature of broiler house at 2 nd week of second period was close to the optimal temperature whereas the inside temperature of broiler house at 3-7 weeks was higher than the optimal temperature. On the other hand, inside relative humidity of broiler house at 3-7 weeks of second period was lower than the optimum relative humidity level.

The general heat and moisture balance for the broiler house calculated in February and March was shown Table 1. Sensible heat dissipated by broiler was ranged from 1.20-4.50 $\mathrm{kcal} \mathrm{h}^{-1}$ in February and March. Moisture released by poultry ranged from $1.30-4.20 \mathrm{~g} \mathrm{~h}^{-1}$ in February and March. The net heat output through the structural elements was ranged from $8.40-14.00 \mathrm{kcal} \mathrm{m}^{-2}{ }^{\circ} \mathrm{C}$

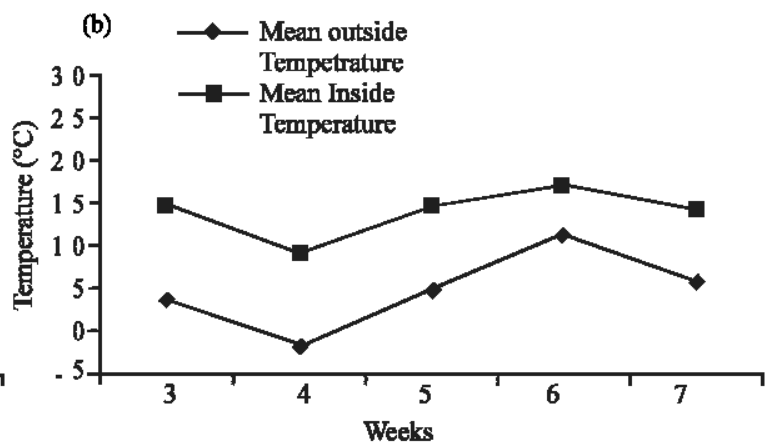

Fig. 1(a,b): The temperature and humidity values of 5 weeks in the first period 

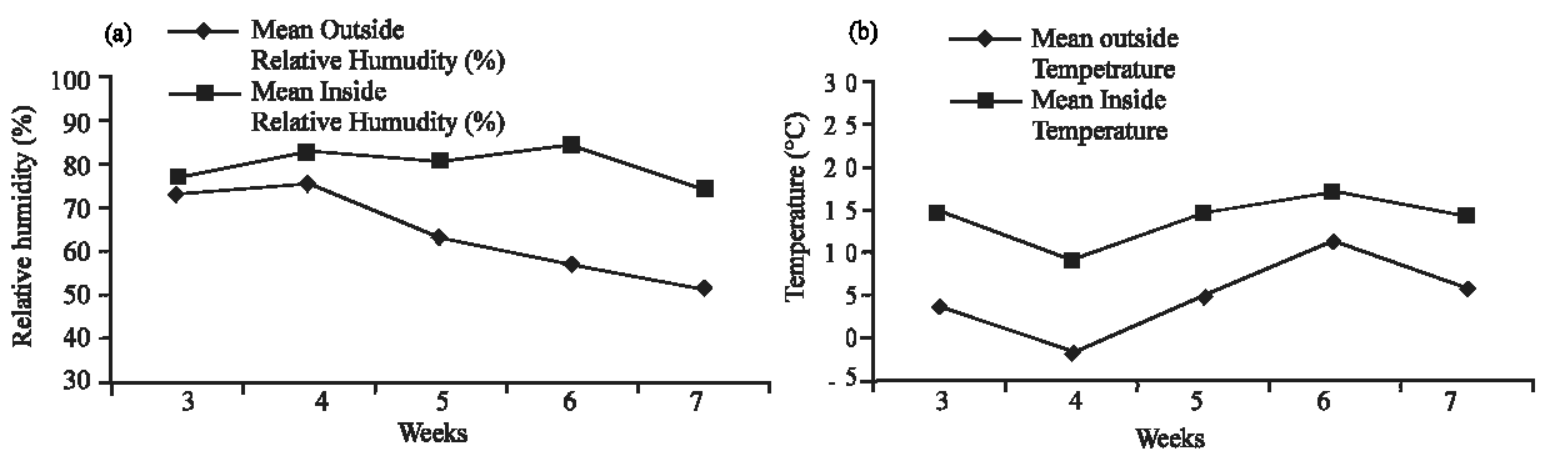

Fig. 2(a, b): The temperature and humidity values of 6 weeks in the second period

Table 1: The general heat and moisture balance for the broiler house calculated in February and March

\begin{tabular}{|c|c|c|c|c|c|c|}
\hline Weeks & Broiler number & $\mathrm{q}_{\mathrm{d}}$ & $\mathrm{W}_{\mathrm{h}}$ & $\mathrm{q}_{\mathrm{v}}$ & Surplus hat & Surplus misture \\
\hline 3 & 520 & 1.20 & 1.30 & 11.90 & -11.60 & 1.30 \\
\hline 4 & 460 & 1.90 & 1.80 & 12.80 & -12.00 & 1.80 \\
\hline 5 & 85 & 2.50 & 2.40 & 12.50 & -12.20 & 2.40 \\
\hline 6 & 325 & 3.30 & 3.20 & 8.40 & -7.10 & 3.20 \\
\hline 7 & 270 & 4.50 & 4.20 & 14.00 & -13.70 & 4.20 \\
\hline
\end{tabular}

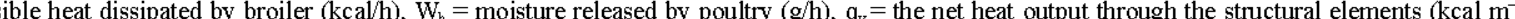
${ }^{\circ} \mathrm{Ch}$,

Table 2: The general heat and moisture balance for the broiler house calculated in August and September

\begin{tabular}{|c|c|c|c|c|c|c|}
\hline Weeks & Broiler number & $\mathrm{q}_{\mathrm{d}}$ & $W_{h}$ & $\mathrm{q}_{\mathrm{y}}$ & Surplus hat & Surplus misture \\
\hline 2 & 920 & 0.80 & 0.80 & 1.10 & -0.30 & 0.80 \\
\hline 3 & 918 & 1.20 & 1.30 & 1.50 & -0.30 & 1.30 \\
\hline 4 & 915 & 1.90 & 1.80 & 2.00 & -0.10 & 1.80 \\
\hline 5 & 911 & 2.50 & 2.40 & 3.10 & -0.60 & 2.40 \\
\hline 6 & 906 & 3.30 & 3.20 & 4.80 & -1.50 & 3.20 \\
\hline 7 & 900 & 4.50 & 4.20 & 3.80 & 0.70 & 4.20 \\
\hline
\end{tabular}

in February and March. The general heat and moisture balance for the broiler house calculated in August and September was shown Table 2. Sensible heat dissipated by broiler was ranged from $0.80-4.50 \mathrm{kcal} \mathrm{h}^{\leftarrow}$. Moisture released by poultry ranged from $0.80-4.20 \mathrm{~g} \mathrm{~h}^{-1}$. The net heat output through the structural elements was ranged from $1.10-3.80 \mathrm{kcal} \mathrm{m}^{-2}{ }^{\circ} \mathrm{C}$.

\section{CONCLUSION}

Although, there is need for supplementary heat during the first period in February and March there is no need for supplementary heat during the first period in August and September for poultry house in Kahr amanaras, Turkey.

\section{ACKNOWLEDGEMENTS}

This study was a part of Msc by S. Boyaci (2005) and supported by the Scientific Research Project Committee of Kahramanmaras Sutcu Imam University, Turkey.

\section{REFERENCES}

Atilgan, A. and H. Koknaroglu, 2006. Cultural energy analysis on broilers reared in different capacity poultry houses. Ital. J. Anim. Sci., 5: 393-400.

Atilgan, A., A. Coskan, H. Oz and E. Isler, 2010. The vacuum system which is new approach to decrease ammonia level use in broiler housing in winter season. Kafkas Univ. Vet. Fak. Derg, 16: 257-262.

Butcher, G.D. and R. Miles, 1996. Heat stress management in broilers. The Veterinary Medicine Large Animal Clinical Sciences Department, Florida Cooperative Extension Service, Institute of Food and Agricultural Sciences, University of Florida, pp: 1-3.

Karaman, A., M. Baylan, M. Karaman and S. Canogullari, 2009. Nutritive value of culban (Vicia peregrina) seeds as dietary protein source for Japanese quail (Coturnix coturnix japonica). J. Anim. Vet. Adv., 8: 839-842.

Lindley, J.A. and J.H. Whitaker, 1996. Agricultural Building and Structures. ASAE, USA., ISBN: 0929355-73-3, pp:1-675. 